\title{
Anxiety and depression levels in prepubertal obese children: a case-control study
}

\author{
This article was published in the following Dove Press journal: \\ Neuropsychiatric Disease and Treatment \\ 3 October 2014 \\ Number of times this article has been viewed
}

\section{Maria Esposito' \\ Beatrice Gallai \\ Michele Roccella ${ }^{3}$ \\ Rosa Marotta ${ }^{4}$ \\ Francesco Lavano ${ }^{4}$ \\ Serena Marianna Lavano ${ }^{4}$ \\ Giovanni Mazzotta ${ }^{5}$ \\ Domenico Bove ${ }^{6}$ \\ Michele Sorrentino' \\ Francesco Precenzano' \\ Marco Carotenuto' \\ 'Clinic of Child and Adolescent Neuropsychiatry, Department of Mental Health, Physical and Preventive Medicine, Second University of Naples, Naples, Italy; ${ }^{2}$ Unit of Child and Adolescent Neuropsychiatry, University of Perugia, Perugia, Italy; ${ }^{3}$ Child Neuropsychiatry, Department of Psychology, University of Palermo, Palermo, Italy; ${ }^{4}$ Department of Psychiatry, "Magna Graecia" University of Catanzaro, Catanzaro, Italy; ${ }^{5}$ Unit of Child and Adolescent Neuropsychiatry, AUSL Umbria 2, Terni, Italy; ${ }^{6}$ Centro per la Diagnosi e Cura dei Disturbi dell'apprendimento e del Comportamento Associazione per la ricerca scientifica Fusis, Alvignano, Italy}

Correspondence: Beatrice Gallai Unit of Child and Adolescent Neuropsychiatry, University of Perugia, Via Enrico dal Pozzo, 06100, Perugia, Italy Tel +39744204506

Fax +39744204506

Email beagallai@gmail.com
Introduction: Childhood obesity has become a worldwide epidemic in Western and in developing countries and has been accompanied by many serious and severe comorbidities, such as diabetes, hypertension, sleep apnea syndrome, depression, dyslipidemia, impaired glucose homeostasis, steatohepatitis, and intracranial hypertension, as well as medical concerns unique to youth, such as accelerated pubertal and skeletal development and orthopedic disorders. To date, no specific studies about the psychological assessment in pediatric obesity are present. Therefore, the aim of this study was to evaluate the putative relationship between psychological troubles and obesity in a sample of school-aged children.

Materials and methods: The study population consists of 148 obese subjects (body mass index $[\mathrm{BMI}]>95$ th percentile) (69 males, mean age $8.9 \pm 1.23$ years) consecutively referred from clinical pediatricians to the Child and Adolescent Neuropsychiatry department at the Second University of Naples. In all subjects, weight, height, and BMI $z$-score were evaluated. In order to assess the anxiety levels and the presence of depressive symptoms, the Children Depression Inventory (CDI) and the Italian Self-Administered Psychiatric Scales for Children and Adolescents (SAFA) were administered. The control group consisted of 273 healthy children (129 males and 144 females) (mean age 9.1 \pm 1.8 years), enrolled in schools within the Campania region of Italy.

Results: No significant differences between the two study groups were found for age ( $8.9 \pm 1.23$ years in the obese sample and $9.1 \pm 1.8$ years in the control group) $(P=0.228)$ or sex (ratio male/female: $69 / 79$ in the obese group versus $129 / 144$ in the control group) ( $P=0.983$ ). Obviously, significant difference was found for the BMI $z$-score $(2.46 \pm 0.31$ in the obese group vs $0.73 \pm 0.51$ in the control group) $(P<0.001)$. The obese subjects showed significant higher level of depressive symptoms (CDI total score) $(16.82 \pm 7.73$ vs $8.2 \pm 2.9)(P<0.001)$ and anxiety (SAFA - Anxiety [SAFA-A]) scale score $(58.71 \pm 11.84$ vs $27.75 \pm 11.5)(P<0.001)$ compared with the control group. Moreover, the Pearson's correlation analysis showed a significantly positive relationship between the BMI $z$-score and both the CDI $(r=0.677 ; P<0.001)$ and SAFA-A scores $(r=0.591 ; P<0.001)$.

Conclusion: Our findings highlighted the importance of assessing the presence of internalizing problems, such as anxiety and depression, in the common management of childhood obesity.

Keywords: childhood obesity, internalizing problems, SAFA, CDI

\section{Introduction}

Childhood obesity has become a worldwide epidemic in Western and in developing countries $^{1,2}$ and has been accompanied by many serious and severe comorbidities, such as diabetes, ${ }^{3}$ hypertension, ${ }^{4,5}$ sleep apnea syndrome, ${ }^{6,7}$ depression, ${ }^{8}$ metabolic alterations, intracranial hypertension, ${ }^{9,10}$ and precocious puberty. ${ }^{11,12}$ The psychiatric aspects related to obesity in pediatric age are still poorly studied, although depressive symptoms seem to be relevant in obese subjects. ${ }^{13-15}$ 
In fact, obesity may be identified as a multifactorial disease, and in recent years many studies attempted to also identify the putative psychological link between obesity (and/or overweight) development and parental relationship of obese subjects. ${ }^{16-23}$

Despite the extensive literature about the role of genetic and metabolic comorbidities, ${ }^{24-34}$ reports about the role of psychological factors in obese children are still scant, probably due to the difficulty of recognizing the psychiatric symptoms in children. ${ }^{35-39}$ On the other hand, body size seems to be the strongest predictor for the development of depressive symptoms, with a curvilinear relationship shown by Cortese et al in $2009 .{ }^{40}$ Researchers found that body mass index (BMI) could be associated with the externalizing problems, such as attention-deficit hyperactivity disorder (ADHD) symptoms also influencing the treatment therapeutic outcome..$^{41-43}$ In this perspective, the link between obesity and psychiatric symptoms appears to be intriguing and still unclarified.

To the best of our knowledge, no specific studies about self-evaluation of internalizing problems in pediatric obese subjects are present in clinical literature. Therefore, the aim of the present study was to evaluate the putative relationship between psychological troubles and obesity, in a sample of school-aged children.

\section{Materials and methods}

The study population consisted of 148 obese subjects (BMI $>95$ th percentile) (69 males and 79 females, with mean age $8.9 \pm 1.23$ years) consecutively referred by clinical pediatricians to the Child and Adolescent Neuropsychiatry department at the Second University of Naples. In all subjects, weight, height, and BMI $z$-score were evaluated.

In order to assess the anxiety levels and the presence of depressive symptoms, the Children Depression Inventory $(\mathrm{CDI})^{44}$ and the Italian Self-Administered Psychiatric Scales for Children and Adolescents (SAFA ${ }^{45}$ were administered.

The exclusion criteria were: allergies, endocrine problems (ie, diabetes), genetic syndromes (such as Prader-Willi syndrome, Down syndrome, Sturge-Weber syndrome, neurofibromatosis), ${ }^{46,47}$ preterm birth, ${ }^{48,49}$ neurological (ie, epilepsy, headache), or psychiatric symptoms (ADHD, depression, behavioral problems, etc.), mental retardation (intelligence quotient [IQ] $\leq 70$ ), previous rehabilitative treatment, ${ }^{50}$ borderline intellectual functioning (IQ ranging from 71 to 84$),{ }^{51,52}$ referred sleep disorders, ${ }^{8,53-59}$ primary nocturnal enuresis, ${ }^{60-62}$ or anticonvulsant ${ }^{63,64}$ or psychoactive drugs administration.
The control group consisted of 273 healthy children (129 males and 144 females, with mean age $9.1 \pm 1.8$ years) enrolled in schools within the Campania region of Italy.

All subjects were recruited from the same urban area and were of Caucasian origin and middle socioeconomic status (class 2 or class 3, corresponding to 28,000-55,000 euros/year to $55,000-75,000$ euros/year, respectively, according to the current Italian economic legislation parameters as previously reported). ${ }^{65-70}$

Informed consent was obtained from all parents. The investigation was carried out in accordance with the principles of the Declaration of Helsinki. ${ }^{71}$ The Departmental Ethics Committee at the Second University of Naples approved the study.

\section{Screening for depressive symptoms}

All children filled out the Italian version of the CDI, ${ }^{72}$ to screen for the presence of depressive symptoms. The CDI is widely used to assess depressive symptomatology in children and adolescents aged $8-17$ years, providing good internal consistency (Cronbach's $\alpha=0.80$ ). The scale is composed of 27 Likert-like items scored from 0 to 2 , with higher scores reflecting more important depressive symptomatology. According to the Italian validation criteria, a score of 19 is considered suggestive of depressive symptoms. ${ }^{73}$ In our study, the five CDI subscale scores (negative mood, interpersonal problems, ineffectiveness, anhedonia, and negative self-esteem) $)^{74,75}$ were not considered because of lack of normative data for the Italian version of the test. ${ }^{73}$

\section{Anxiety assessment}

All subjects filled out the SAFA - Anxiety (SAFA-A) scale, ${ }^{76}$ a self-administered questionnaire providing an emotional profile in children. Specifically, in 2012, the SAFA-A scale was validated for the Italian pediatric population by Nacinovich et al. ${ }^{76}$

The SAFA-A scale was created to assess internalizing problems and comprises a specific subscale for 8- to 10-yearold children (SAFA A/e), for 11- to 13-year-old children (SAFA A/m), and for 14- to 18-year-olds (SAFA A/s). ${ }^{77}$

The SAFA A/e scale consists of 42 items (40 negative and two positive affirmations) grouped into four subscales: Generalized Anxiety (ten items); Social Anxiety (ten items); Separation-Loss Anxiety (ten items); and School-Related Anxiety (ten items). ${ }^{77}$ The scale is characterized by good reliability in healthy subjects (Cronbach's $\alpha=0.857$ ). ${ }^{77}$ 


\section{Statistical analysis}

In order to compare the characteristics (age, sex, and BMI $z$-score) and the CDI and SAFA-A tests results between obese children and controls, the chi-square test and unpaired $t$-test, where appropriate, were applied. Then, to explore the relationship between the BMI $z$-score and the CDI and SAFA-A scales, Pearson's correlation test was applied. For all statistical analysis, $P$-values $<0.05$ were considered significant.

All data were coded and analyzed using the commercially available STATISTICA 6.0 package for Windows (StatSoft, Inc., Tulsa, OK, USA).

\section{Results}

No significant differences between the two study groups were found for age $(8.9 \pm 1.23$ years in the obese sample and $9.1 \pm 1.8$ years in the control group) $(P=0.228)$ or sex (ratio male/female: $69 / 79$ in the obese group versus $129 / 144$ in the control group) $(P=0.983)$. Obviously, significant difference was found for the BMI $z$-score $(2.46 \pm 0.31$ in the obese group versus $0.73 \pm 0.51$ in the control group) $(P<0.001)$.

The obese subjects showed significant higher level of depressive symptoms (CDI total score) (16.82 \pm 7.73 vs $8.2 \pm 2.9)(P<0.001)$ and in the SAFA-A total scale score $(58.71 \pm 11.84$ vs $27.75 \pm 11.5)(P<0.001)$ compared with the control group. In the obese group, no significant differences were found between males and females in depression (17.19 \pm 8.05 vs $15.96 \pm 7.84 ; P=0.349)$ and anxiety $(56.11 \pm 13.01$ vs 59.02 \pm 15.36$)(P=0.219)$ levels.

Moreover, the Pearson's correlation analysis showed a significantly positive relationship between the BMI $z$-score and both the CDI $(r=0.677 ; P<0.001)$ and SAFA-A scores $(r=0.591 ; P<0.001)$.

\section{Discussion}

The main finding of the present study is the higher presence of anxiety and depression levels in a population of obese prepubertal subjects.

The presence of high rate of internalizing symptoms, such as anxiety and depression, among obese children could also be supported by some neurobiological evidence. ${ }^{78}$ Pervanidou et al reported that the imbalance in hypothalamic-pituitary-adrenal axis was involved in anxiety disorders, depression, and obesity. ${ }^{78}$ Moreover, cortisol level alterations may also be found in obese children, in linear correlation with the degree of psychological/ emotional distress. ${ }^{78}$

On the other hand, many authors have identified a putative link between obesity and internalizing difficulties, ${ }^{79}$ poorer quality of life,${ }^{80}$ more profound social issues, ${ }^{81}$ and increased behavioral problems. ${ }^{82,83}$ In this picture, obese children seem to be more depressed, ${ }^{84}$ hopeless, ${ }^{85}$ and suicidal, ${ }^{85}$ as well as to have lower self-esteem and lower life satisfaction ${ }^{86}$ compared with healthy controls, although the findings are not conclusive.

In fact, studies have generally focused on large community-based samples or small clinic-based samples, but in large community samples, the number of children who are obese is often limited, while in clinic-based studies, the sample sizes tend to be small, masking the considerable psychological variability among obese individuals..$^{87,88}$

In this light, critical for treatment of these youth is the identification and/or treatment of psychological conditions, which otherwise could prevent successful treatment in a pediatric weight management clinic and may even lead to continued rapid, abnormal weight gain. ${ }^{89}$

On the other hand, overweight and depression are two pressing issues among school-aged children, which have negative impacts on their growth and development, school performance, and family relationships, and which are an important precursor to psychopathology, ${ }^{90}$ and in this light, our findings about the significant relationship between depressive symptoms and obesity may be interpreted.

The effective mechanisms that may explain the relationship between symptoms of depression and obesity remain unclear, although some hypotheses may be proposed. One possibility is that symptoms of depression promote excess weight gain during adolescence via reduced physical activity and consequently, lower energy expenditure. From a cognitive-behavioral theoretical framework, elevated symptoms of depression develop and are maintained as a result of a negative view of the self, one's experiences, and the future. ${ }^{91}$ In particular, it has been evidenced that obese subjects showed higher levels of anhedonia as prompting behavioral withdrawal from physical exercise, which further exacerbates depressed mood. ${ }^{92}$ In support of this hypothesis, a number of cross-sectional studies have found an inverse association between adolescents' symptoms of depression and self-reported physical activity, exercise, or sports participation. ${ }^{93-97}$ In contrast, in a large sample of young adolescent girls, depressive symptoms were not significantly associated with physical activity as assessed by accelerometer, an ambulatory device used to objectively monitor moderate-to-vigorous physical activity. ${ }^{98}$ Longitudinal data indicate that increases in adolescents' depressive symptoms are associated with decreases in self-reported leisure-time physical activity. ${ }^{99}$ 
Although it seems obvious that obese children and adolescents would likely be at higher risk for psychological problems, the mediating factors in the relationship between psychological problems and obesity are still not well established. Obesity is a complex disorder with an equally complex etiology and is thus associated with complex behaviors and psychological outcomes that make it difficult to study in children. $^{100-109}$

Limitations of the present study can be identified in the small number of obese children recruited and in the use of self-administered psychological tools. Notwithstanding these limitations, our study could suggest the psychological screening for internalizing problems as mandatory among obese children.

In conclusion, our findings highlighted the importance of assessing the presence of internalizing problems, such as anxiety and depression, in the common management of childhood obesity.

\section{Disclosure}

The authors report no conflicts of interest in this work.

\section{References}

1. Rokholm B, Baker JL, Sørensen TI. The levelling off of the obesity epidemic since the year 1999 - a review of evidence and perspectives. Obes Rev. 2010;11(12):835-846.

2. Waters E, de Silva-Sanigorski A, Hall BJ, et al. Interventions for preventing obesity in children. Cochrane Database Syst Rev. 2011;12: CD001871.

3. Brufani C, Crinò A, Fintini D, Patera PI, Cappa M, Manco M. Systematic review of metformin use in obese nondiabetic children and adolescents. Horm Res Paediatr. 2013;80(2):78-85.

4. Gröber-Grätz D, Widhalm K, de Zwaan M, et al. Body mass index or waist circumference: which is the better predictor for hypertension and dyslipidemia in overweight/obese children and adolescents? Association of cardiovascular risk related to body mass index or waist circumference. Horm Res Paediatr. 2013;80(3):170-178.

5. Kaur S, Sachdev H, Dwivedi SN, Lakshmi R, Kapil U, Sareen N. Association of obesity with hypertension amongst school-age children belonging to lower income group and middle income group in national capital territory of Delhi. Indian J Community Med. 2013; 38(3):175-179.

6. Van Eyck A, Van Hoorenbeeck K, De Winter BY, et al. Sleepdisordered breathing and C-reactive protein in obese children and adolescents. Sleep Breath. 2014;18(2):335-340.

7. Stefanini Dde O, Barros EL, Stefanini R, Pradella-Hallinan ML, Pignatari SS, Fujita RR. Comparing the clinical profile of non obese children with sleep apnea and snoring. Braz J Otorhinolaryngol. 2012; 78(5):22-26.

8. Carotenuto M, Esposito M, Parisi L, et al. Depressive symptoms and childhood sleep apnea syndrome. Neuropsychiatr Dis Treat. 2012;8: 369-373.

9. Must A, Strauss RS. Risks and consequences of childhood and adolescent obesity. Int J Obes Relat Metab Disord. 1999;23 Suppl 2: S2-S11.

10. Weiss R, Dziura J, Burgert TS, et al. Obesity and the metabolic syndrome in children and adolescents. N Engl J Med. 2004;350(23):2362-2374.
11. Russell DL, Keil MF, Bonat SH, et al. The relation between skeletal maturation and adiposity in African American and Caucasian children. J Pediatr. 2001;139(6):844-848.

12. Taylor ED, Theim KR, Mirch MC, et al. Orthopedic complications of overweight in children and adolescents. Pediatrics. 2006;117(6): 2167-2174.

13. Blaine B. Does depression cause obesity?: a meta-analysis of longitudinal studies of depression and weight control. J Health Psychol. 2008; 13(8):1190-1197.

14. de Wit L, Luppino F, van Straten A, Penninx B, Zitman F, Cuijpers P. Depression and obesity: a meta-analysis of community-based studies. Psychiatry Res. 2010;178(2):230-235.

15. Luppino FS, de Wit LM, Bouvy PF, et al. Overweight, obesity, and depression: a systematic review and meta-analysis of longitudinal studies. Arch Gen Psychiatry. 2010;67(3):220-229.

16. Gibson LY, Byrne SM, Davis EA, Blair E, Jacoby P, Zubrick SR. The role of family and maternal factors in childhood obesity. Med J Aust. 2007;186(11):591-595.

17. Roblin L. Childhood obesity: food, nutrient, and eating-habit trends and influences. Appl Physiol Nutr Metab. 2007;32(4):635-645.

18. Ochoa MC, Moreno-Aliaga MJ, Martínez-González MA, Martínez JA, Marti A; GENOI Members. Predictor factors for childhood obesity in a Spanish case-control study. Nutrition. 2007;23(5):379-384.

19. Howard KR. Childhood overweight: parental perceptions and readiness for change. $J$ Sch Nurs. 2007;23(2):73-79.

20. Murnan J, Price JH, Telljohann SK, Dake JA, Boardley D. Parents' perceptions of curricular issues affecting children's weight in elementary schools. J Sch Health. 2006;76(10):502-511.

21. Brewis A, Gartin M. Biocultural construction of obesogenic ecologies of childhood: parent-feeding versus child-eating strategies. Am J Hum Biol. 2006;18(2):203-213.

22. Jackson D, Mannix J, Faga P, McDonald G. Overweight and obese children: mothers' strategies. $J$ Adv Nurs. 2005;52(1):6-13.

23. Carlisle LK, Gordon ST, Sothern MS. Can obesity prevention work for our children? J La State Med Soc. 2005;157 Spec No 1:S34-S41.

24. Wang CP, Chung FM, Shin SJ, Lee YJ. Congenital and environmental factors associated with adipocyte dysregulation as defects of insulin resistance. Rev Diabet Stud. 2007;4(2):77-84.

25. Barness LA. Obesity in children. Fetal Pediatr Pathol. 2007;26(2): $75-85$.

26. Almasy L, Göring HH, Diego V, et al. A novel obesity locus on chromosome 4q: the Strong Heart Family Study. Obesity (Silver Spring). 2007;15(7):1741-1748.

27. Grunnet L, Vielwerth S, Vaag A, Poulsen P. Birth weight is nongenetically associated with glucose intolerance in elderly twins, independent of adult obesity. J Intern Med. 2007;262(1):96-103.

28. Kolovou GD, Anagnostopoulou KK, Salpea KD, Mikhailidis DP. The prevalence of metabolic syndrome in various populations. Am J Med Sci. 2007;333(6):362-371.

29. Santoro N, Perrone L, Cirillo G, et al. Effect of the melanocortin-3 receptor C17A and G241A variants on weight loss in childhood obesity. Am J Clin Nutr. 2007;85(4):950-953.

30. Santoro N, Cirillo G, Amato A, et al. Insulin gene variable number of tandem repeats (INS VNTR) genotype and metabolic syndrome in childhood obesity. J Clin Endocrinol Metab. 2006;91(11):4641-4644.

31. Santoro N, Miraglia Del Giudice E, Coppola F, Luongo C, Perrone L. Growth acceleration in prepubertal obese children: role of hyperinsulinaemia. Acta Paediatr. 2006;95(7):887-888.

32. Santoro N, del Giudice EM, Cirillo G, et al. An insertional polymorphism of the proopiomelanocortin gene is associated with fasting insulin levels in childhood obesity. $J$ Clin Endocrinol Metab. 2004;89(10):4846-4849.

33. Miraglia del Giudice E, Santoro N, Cirillo G, et al. Molecular screening of the ghrelin gene in Italian obese children: the Leu72Met variant is associated with an earlier onset of obesity. Int J Obes Relat Metab Disord. 2004;28(3):447-450. 
34. Miraglia Del Giudice E, Cirillo G, Nigro V, et al. Low frequency of melanocortin-4 receptor (MC4R) mutations in a Mediterranean population with early-onset obesity. Int J Obes Relat Metab Disord. 2002; 26(5):647-651.

35. Rosenberger PH, Henderson KE, Bell RL, Grilo CM. Associations of weight-based teasing history and current eating disorder features and psychological functioning in bariatric surgery patients. Obes Surg. 2007;17(4):470-477.

36. Petroni ML, Villanova N, Avagnina S, et al; QUOVADIS Study Group. Psychological distress in morbid obesity in relation to weight history. Obes Surg. 2007;17(3):391-399.

37. Anderson SE, Cohen P, Naumova EN, Must A. Association of depression and anxiety disorders with weight change in a prospective community-based study of children followed up into adulthood. Arch Pediatr Adolesc Med. 2006;160(3):285-291.

38. Nagai N, Matsumoto T, Kita H, Moritani T. Autonomic nervous system activity and the state and development of obesity in Japanese school children. Obes Res. 2003;11(1):25-32.

39. Grilo CM, Masheb RM. Childhood psychological, physical, and sexual maltreatment in outpatients with binge eating disorder: frequency and associations with gender, obesity, and eating-related psychopathology. Obes Res. 2001;9(5):320-325.

40. Cortese S, Falissard B, Angriman M, et al. The relationship between body size and depression symptoms in adolescents. J Pediatr. 2009; 154(1):86-90.

41. Cortese S, Castellanos FX. The relationship between ADHD and obesity: implications for therapy. Expert Rev Neurother. 2014;14(5): 473-479.

42. Cortese S, Moreira Maia CR, Rohde LA, Morcillo-Peñalver C, Faraone SV. Prevalence of obesity in attention-deficit/hyperactivity disorder: study protocol for a systematic review and meta-analysis. BMJ Open. 2014;4(3):e004541.

43. Cortese S, Morcillo Peñalver C. Comorbidity between ADHD and obesity: exploring shared mechanisms and clinical implications. Postgrad Med. 2010;122(5):88-96.

44. Kovacs M. Children Depression Inventory. Toronto, ON: Multi Health Systems, Inc.; 1992.

45. Cianchetti C, Sannio Fancello G. Scale Psichiatriche di Autosomministrazione per Fanciulli e Adolescenti (SAFA) [Self-administered psychiatric scales for children and adolescents]. Firenze: Organizzazioni Speciali; 2001. Italian.

46. Carotenuto M, Esposito M. Nutraceuticals safety and efficacy in migraine without aura in a population of children affected by neurofibromatosis type I. Neurol Sci. 2013;34(11):1905-1909.

47. Parisi L, Di Filippo T, La Grutta S, et al. Sturge-Weber syndrome: a report of 14 cases. Mental Illness. 2013;5e 7:26-28.

48. Guzzetta A, Pizzardi A, Belmonti V, et al. Hand movements at 3 months predict later hemiplegia in term infants with neonatal cerebral infarction. Dev Med Child Neurol. 2010;52(8):767-772.

49. Guzzetta A, D'Acunto MG, Carotenuto M, et al. The effects of preterm infant massage on brain electrical activity. Dev Med Child Neurol. 2011; 53 Suppl 4:S46-S51.

50. Esposito M, Gimigliano F, Ruberto M, et al. Psychomotor approach in children affected by nonretentive fecal soiling (FNRFS): a new rehabilitative purpose. Neuropsychiatr Dis Treat. 2013;9: 1433-1441.

51. Esposito M, Carotenuto M. Intellectual disabilities and power spectra analysis during sleep: a new perspective on borderline intellectual functioning. J Intellect Disabil Res. 2014;58(5):421-429.

52. Esposito M, Carotenuto M. Borderline intellectual functioning and sleep: the role of cyclic alternating pattern. Neurosci Lett. 2010;485(2): 89-93.

53. Carotenuto M, Santoro N, Grandone A, et al. The insulin gene variable number of tandem repeats (INS VNTR) genotype and sleep disordered breathing in childhood obesity. J Endocrinol Invest. 2009; 32(9):752-755.
54. Carotenuto M, Bruni O, Santoro N, Del Giudice EM, Perrone L, Pascotto A. Waist circumference predicts the occurrence of sleepdisordered breathing in obese children and adolescents: a questionnairebased study. Sleep Med. 2006;7(4):357-361.

55. Carotenuto M, Guidetti V, Ruju F, Galli F, Tagliente FR, Pascotto A. Headache disorders as risk factors for sleep disturbances in school aged children. J Headache Pain. 2005;6(4):268-270.

56. Esposito M, Parisi P, Miano S, Carotenuto M. Migraine and periodic limb movement disorders in sleep in children: a preliminary case-control study. J Headache Pain. 2013;14:57.

57. Carotenuto M, Gallai B, Parisi L, Roccella M, Esposito M. Acupressure therapy for insomnia in adolescents: a polysomnographic study. Neuropsychiatr Dis Treat. 2013;9:157-162.

58. Carotenuto M, Gimigliano F, Fiordelisi G, Ruberto M, Esposito M. Positional abnormalities during sleep in children affected by obstructive sleep apnea syndrome: the putative role of kinetic muscular chains. Med Hypotheses. 2013;81(2):306-308.

59. Carotenuto M, Esposito M, Pascotto A. Facial patterns and primary nocturnal enuresis in children. Sleep Breath. 2011;15(2): 221-227.

60. Esposito M, Gallai B, Parisi L, et al. Primary nocturnal enuresis as a risk factor for sleep disorders: an observational questionnaire-based multicenter study. Neuropsychiatr Dis Treat. 2013;9:437-443.

61. Esposito M, Carotenuto M, Roccella M. Primary nocturnal enuresis and learning disability. Minerva Pediatr. 2011;63(2):99-104.

62. Esposito M, Gallai B, Parisi L, et al. Visuomotor competencies and primary monosymptomatic nocturnal enuresis in prepubertal aged children. Neuropsychiatr Dis Treat. 2013;9:921-926.

63. Coppola G, Auricchio G, Federico R, Carotenuto M, Pascotto A. Lamotrigine versus valproic acid as first-line monotherapy in newly diagnosed typical absence seizures: an open-label, randomized, parallelgroup study. Epilepsia. 2004;45(9):1049-1053.

64. Coppola G, Licciardi F, Sciscio N, Russo F, Carotenuto M, Pascotto A. Lamotrigine as first-line drug in childhood absence epilepsy: a clinical and neurophysiological study. Brain Dev. 2004;26(1):26-29.

65. Esposito M, Gallai B, Parisi L, et al. Maternal stress and childhood migraine: a new perspective on management. Neuropsychiatr Dis Treat. 2013;9:351-355.

66. Esposito M, Parisi L, Gallai B, et al. Attachment styles in children affected by migraine without aura. Neuropsychiatr Dis Treat. 2013;9:1513-1519.

67. Esposito M, Roccella M, Gallai B, et al. Maternal personality profile of children affected by migraine. Neuropsychiatr Dis Treat. 2013;9:1351-1358.

68. Esposito M, Marotta R, Gallai B, et al. Temperamental characteristics in childhood migraine without aura: a multicenter study. Neuropsychiatr Dis Treat. 2013;9:1187-1192.

69. Esposito M, Antinolfi L, Gallai B, et al. Executive dysfunction in children affected by obstructive sleep apnea syndrome: an observational study. Neuropsychiatr Dis Treat. 2013;9:1087-1094.

70. Esposito M, Gallai B, Parisi L, et al. Self-concept evaluation and migraine without aura in childhood. Neuropsychiatr Dis Treat. 2013;9:1061-1066.

71. wma.net [homepage on the Internet]. WMA Declaration of Helsinki ethical principles for medical research involving human subjects. World Medical Association; 1964 [updated October 2013; cited April 25, 2013]. Available from: http://www.wma.net/en/30publications/10policies/b3/. Accessed August 26, 2014.

72. Kovacs M. [Children's Depression Inventory]. Firenze: Organizzazioni Speciali; 1988. Italian.

73. Frigerio A, Pesenti S, Molteni M, Snider J, Battaglia M. Depressive symptoms as measured by the CDI in a population of northern Italian children. Eur Psychiatry. 2001;16(1):33-37.

74. Saylor CF, Finch AJ, Spirito A, Bennett B. The children's depression inventory: a systematic evaluation of psychometric properties. $J$ Consult Clin Psychol. 1984;52(6):955-967. 
75. Timbremont B, Braet C, Dreessen L. Assessing depression in youth: relation between the Children's Depression Inventory and a structured interview. J Clin Child Adolesc Psychol. 2004;33(1):149-157.

76. Nacinovich R, Gadda S, Maserati E, Bomba M, Neri F. Preadolescent anxiety: an epidemiological study concerning an Italian sample of 3,479 nine-year-old pupils. Child Psychiatry Hum Dev. 2012;43(1):27-34.

77. Busnelli C, Dall'Aglio E, Faina P. Questionario Scala d'Ansia per l'Eta Evolutiva: Manuale di Istruzioni [Anxiety scale for developmental age questionnaire: handbook]. Firenze: Organizzazioni Speciali; 1974. Italian.

78. Pervanidou P, Bastaki D, Chouliaras G, et al. Circadian cortisol profiles, anxiety and depressive symptomatology, and body mass index in a clinical population of obese children. Stress. 2013;16(1):34-43.

79. Buddeberg-Fischer B, Klaghofer R, Reed V. Associations between body weight psychiatric disorders and body image in female adolescents. Psychother Psychosom. 1999;86(6):325-332.

80. Schwimmer JB, Burwinkle TM, Varni JW. Heath related quality of life of severely obese children and adolescents. JAMA. 2003;289(14): 1813-1819.

81. Strauss RS, Pollack HA. Social marginalization of overweight children. Arch Pediatr Adolesc Med. 2003;157(8):746-752.

82. Mustillo S, Worthman C, Erkanli A, Keeler G, Angold A, Costello EJ. Obesity and psychiatric disorder: developmental trajectories. Pediatrics. 2003;111(4 Pt 1):851-859.

83. Young-Hyman D, Schlundt DG, Herman-Wenderoth L, Bozylinski K. Obesity, appearance, and psychosocial adaptation in young African American children. J Pediatr Psychol. 2003;28(7):463-472.

84. Pesa JA, Syre TR, Jones E. Psychosocial differences associated with body weight among female adolescents: the importance of body image. J Adolesc Health. 2000;26(5):330-337.

85. Falkner NH, Neumark-Sztainer D, Story M, Jeffery RW, Beuhring T, Resnick MD. Social, educational, and psychological correlates of weight status in adolescents. Obes Res. 2001;9(1):32-42.

86. Eisenberg ME, Neumark-Sztainer D, Story M. Associations of weightbased teasing and emotional well-being among adolescents. Arch Pediatr Adolesc Med. 2003;157(8):733-738.

87. Faith MS, Calamaro CJ, Dolan MS, Pietrobelli A. Mood disorders and obesity. Curr Opin Psychiatry. 2004;17:9-13.

88. Gilbert V, Zipper E, Dabbas M, et al. Mental disorders in obese children and adolescents. Psychosom Med. 2004;66(3):387-394.

89. Phillips BA, Gaudette S, McCracken A, et al. Psychosocial functioning in children and adolescents with extreme obesity. J Clin Psychol Med Settings. 2012;19(3):277-284.

90. Lin FG, Hsieh YH, Tung HJ. Interactive effects of family socioeconomic status and body mass index on depression in school-aged children. Asia Pac J Clin Nutr. 2012;21(1):64-72.

91. Beck AT. Cognitive Therapy and the Emotional Disorders. New York, NY: International Universities Press; 1976.

92. Lewinsohn PM, Youngren MA, Grosscup SJ. Reinforcement and depression. In: Dupue RA, editor. The Psychobiology of Depressive Disorders: Implications for the Effects of Stress. New York, NY: Academic Press; 1979:291-316.

93. Field T, Diego M, Sanders C. Adolescent depression and risk factors. Adolescence. 2001;36(143):491-498.
94. Dishman RK, Hales DP, Pfeiffer KA, et al. Physical self-concept and self-esteem mediate cross-sectional relations of physical activity and sport participation with depression symptoms among adolescent girls. Health Psychol. 2006;25(3):396-407.

95. Haarasilta LM, Marttunen MJ, Kaprio JA, Aro HM. Correlates of depression in a representative nationwide sample of adolescents (15-19 years) and young adults (20-24 years). Eur J Public Health. 2004;14(3):280-285.

96. Kirkcaldy BD, Shephard RJ, Siefen RG. The relationship between physical activity and self-image and problem behaviour among adolescents. Soc Psychiatry Psychiatr Epidemiol. 2002;37(11):544-550.

97. Norris R, Carroll D, Cochrane R. The effects of physical activity and exercise training on psychological stress and well-being in an adolescent population. J Psychosom Res. 1992;36(1):55-65.

98. Johnson CC, Murray DM, Elder JP, et al. Depressive symptoms and physical activity in adolescent girls. Med Sci Sports Exerc. 2008;40(5): 818-826.

99. Motl RW, Birnbaum AS, Kubik MY, Dishman RK. Naturally occurring changes in physical activity are inversely related to depressive symptoms during early adolescence. Psychosom Med. 2004;66(3): 336-342.

100. De Niet JE, Naiman DI. Psychosocial aspects of childhood obesity. Minerva Pediatr. 2011;63(6):491-505.

101. Janicke DM, Harman JS, Kelleher KJ, Zhang J. Psychiatric diagnosis in children and adolescents with obesity-related health conditions. J Dev Behav Pediatr. 2008;29(4):276-284.

102. Rofey DL, Kolko RP, Iosif AM, et al. A longitudinal study of childhood depression and anxiety in relation to weight gain. Child Psychiatry Hum Dev. 2009;40(4):517-526.

103. Zametkin AJ, Zoon CK, Klein HW, Munson S. Psychiatric aspects of child and adolescent obesity: a review of the past 10 years. $\mathrm{J} \mathrm{Am}$ Acad Child Adolesc Psychiatry. 2004;43(2):134-150.

104. Britz B, Siegfried W, Ziegler A, et al. Rates of psychiatric disorders in a clinical study group of adolescents with extreme obesity and in obese adolescents ascertained via a population based study. Int J Obes Relat Metab Disord. 2000;24(12):1707-1714.

105. Van Vlierberghe L, Braet C, Goossens L, Mels S. Psychiatric disorders and symptom severity in referred versus non-referred overweight children and adolescents. Eur Child Adolesc Psychiatry. 2009;18(3):164-173.

106. Erickson SJ, Robinson TN, Haydel KF, Killen JD. Are overweight children unhappy?: body mass index, depressive symptoms, and overweight concerns in elementary school children. Arch Pediatr Adolesc Med. 2000;154(9):931-935.

107. Needham BL, Crosnoe R. Overweight status and depressive symptoms during adolescence. J Adolesc Health. 2005;36(1):48-55.

108. Wardle J, Williamson S, Johnson F, Edwards C. Depression in adolescent obesity: cultural moderators of the association between obesity and depressive symptoms. Int J Obes (Lond). 2006;30(4):634-643.

109. Daniels J. Weight and weight concerns: are they associated with reported depressive symptoms in adolescents? J Pediatr Health Care. 2005;19(1):33-41.
Neuropsychiatric Disease and Treatment

\section{Publish your work in this journal}

Neuropsychiatric Disease and Treatment is an international, peerreviewed journal of clinical therapeutics and pharmacology focusing on concise rapid reporting of clinical or pre-clinical studies on a range of neuropsychiatric and neurological disorders. This journal is indexed on PubMed Central, the 'PsycINFO' database and CAS,

\section{Dovepress}

and is the official journal of The International Neuropsychiatric Association (INA). The manuscript management system is completely online and includes a very quick and fair peer-review system, which is all easy to use. Visit http://www.dovepress.com/testimonials.php to read real quotes from published authors. 